University of South Florida

DIGITAL COMMONS

@ UNIVERSITY OF SOUTH FLORIDA
Digital Commons @ University of

South Florida

$11-2000$

\title{
The Florida Department of Transportation Statewide Transit Training Program
}

CUTR

Follow this and additional works at: https://digitalcommons.usf.edu/cutr_nctr

\section{Scholar Commons Citation}

CUTR, "The Florida Department of Transportation Statewide Transit Training Program" (2000). Research Reports. 4.

https://digitalcommons.usf.edu/cutr_nctr/4

This Technical Report is brought to you for free and open access by the National Center for Transit Research (NCTR) Archive (2000-2020) at Digital Commons @ University of South Florida. It has been accepted for inclusion in Research Reports by an authorized administrator of Digital Commons @ University of South Florida. For more information, please contact digitalcommons@usf.edu. 


\section{FINAL REPORT \\ For the Period of December 1999 through November 30, 2000 \\ Florida Transit Training Program (1999/2000) \\ Florida Technical Assistance Program (1999/2000)}

The following progress report is intended to highlight the significant activities of the Florida Transit Training Program and Florida Technical Assistant Program. Not all requests received are noted below.

\section{Transit Training Program}

Accomplishments/Significant Findings

In an effort to identify subject areas most important to Florida's transit agencies, CUTR developed and distributed a survey instruments provided as Attachment A. Based on the results of this survey found in Attachment B, a two "FTA Regulations for Dummies" workshops were offered at CUTR. The courses were contracted and taught by McDonald Transit Associates and offered in May and September. Both sessions were very well attended (30 plus students in each workshop) and feedback from the participants was excellent. Copies of the course evaluation forms are in Attachment C.

A three-day, Productivity and Supervisor Skills workshop was offered in November. The course was contracted and taught by Dave Cyra. General feedback from the course indicated very positive results. The course evaluations are included in Attachment $D$, as well as a copy of the reminder post cards that were sent prior to the registration deadline, Attachment $\mathrm{E}$.

A three-day, Management and Productivity Skills workshop has been scheduled and will be offered in December. The course has been contracted to be taught by Dave Cyra. A post card reminder was sent prior to the registration deadline, Attachment E.

A "Demand Responsive Operational Efficiencies" course was offered via the National Transit Institute at the 2000 FTA Annual Conference in Clearwater. This 
course was very well attended and well received. Copies of the course evaluation forms are provided in Attachment $\mathrm{F}$.

Florida Bus Operator Training Certification- There have been two Florida Bus Operator Training Advisory Board meetings in July and October of 2000. An Operator Training Survey (Attachment G) was distributed to all Florida Transit Agencies; the results of the survey are attached (Attachment $\mathrm{H}$ ). Between the Advisory Board Meeting and the surveys, the transit agencies have given us great feedback on the direction the program needs to take. This partnership with the transit agencies will help us create a voluntary certification program that will help us help them. Additionally, we are partnering with the Transit Safety Institute (TSI) to coordinate the offering of more Federal Certification courses here in Florida.

CUTR began developing an enhanced public transportation contact database in conjunction with other faculty at CUTR involved in transit operations and transit maintenance training and technical assistance.

\section{Technical Assistance Program}

Accomplishments/Significant Findings

PalmTran Budget Assistance- CUTR staff reviewed PalmTran's proposed budget to help them estimate how a revenue based new fare structure might aid in avoiding reduced service (and reduced revenues from that reduced service). Joel Volinski and Dennis Hinebaugh from CUTR's staff, reviewed the accuracy of their projections for the budget, and offered specific feedback and suggestions for modifying their estimates of the effects on Palmtran's service proposals. In addition, CUTR's staff traveled to Palm Beach for the presentation of findings at the budget workshop to help answer questions for the Palm Beach County Commissioners. Perry Maull, Palm Trans' Director, did modify his budget projections in accordance with CUTR's suggestions, and the Board unanimously approved PalmTran's budget for FY 2001. 
Polk Eligibility-Polk County Transit Services (PCTS) began operating a fixedroute bus system in May 2000, and provides the associated complementary ADA paratransit service. PCTS has also been providing complementary paratransit service for the Winter Haven fixed route bus service. Because of the magnitude of the service area, CUTR assisted PCTS in developing a strict application for ADA eligibility and trained the staff in ADA guidelines and laws.

Copies of the materials are included in Attachment I.

Lakeland Area Mass Transit District (LAMTD)- LAMTD was looking for technical assistance in identifying their AVL needs. They needed help in reviewing and summarizing AVL systems as well as applying this technology specifically to LAMTD's operations and goals. This project is still underway. On November 9 , 2000, CUTR staff met with LAMTD to discuss further developments with LAMTD and Motorola.

VOTRAN requested technical assistance on evaluating and purchasing different types if AVL and APTS systems. Consequently, CUTR arranged for a peer evaluation to be conducted by the ITS Peer to Peer Network. Peer systems to VOTRAN have arranged for a visit to their facility and an overview of their operations. Once VOTRAN has met with it's peers, CUTR will create an RFP or bid package for VOTRAN to purchase appropriate ITS services.

Growth Management and Public Transit in Florida- The development of this report was request by LYNX to describe the growth management process in Florida as well as how transit planning effects the process. A copy of the report enclosed in Attachment $\mathrm{J}$.

FTA Conference- CUTR assistant FTA in organizing a relevant and successful agenda for the Florida Transit Association's Annual Conference. CUTR developed and drafted an agenda, organized and moderated round tables discussions, identified interesting topics for discussion, contact key government officials and invited them to make presentations. 
State Road 200 Route- CUTR provided assistance to SUNTRAN to help them address the feasibility of establishing a new route on State Road 200 to serve a retirement community. CUTR staff, including Chris DeAnnuntis and Dennis Hinebaugh, visited SUNTRAN in July to provide direction to SUNTRAN on the feasibility of adding this route.

Jacksonville MPO- The MPO requests that someone from CUTR make a presentation in July on ADA eligibility and service area considerations. CUTR's staff member, Jennifer Hardin, created and delivered an ADA eligibility presentation to the Jacksonville MPO on ADA transportation requirements for accessible fixed route systems and complimentary paratransit transportation provisions.

LAMTD asked CUTR to assist them with determining a way in which to allocate trips and revenues the US 92 corridor where LAMTD and Winter Haven Area Transit (W.H.A.T.) connect. CUTR staff, Amber Reep, Lisa Staes and Rob Gregg met with Steve Githens, LAMTD's Director on November 9, 2000 to provide guidance in this issue. 